\title{
Access to Job Market: Findings from A Venture Development Program for Marginalized Unemployed Youth in Kampala Uganda
}

\author{
Deborah Sarah Nakirijja ${ }^{1}$, Rogers Kasirye ${ }^{2 *}$, Anna Nabulya ${ }^{2}$ \\ ${ }^{1}$ Huazhong University of Science and Technology, Wuhan PR. China \\ ${ }^{2}$ Uganda Youth Development Link (UYDEL) \\ *Corresponding author email: kasiryer@yahoo.com
}

Received: 27 May 2019 / Revised: 04 July 2019 / Accepted: 08 July 2019 / Published: 18 July 2019

\begin{abstract}
Majority youths (uneducated/unskilled) in Uganda face challenges identified with unemployment and high-risk practices. An estimated $78 \%$ of Ugandan youth are jobless, need economic capital and life skills. The high rate of unemployment is principally brought about by the absence of employable skills, the lack of capacity of the economy to create as many jobs for the unskilled youth and the everincreasing population driven by the rural-urban drift. The survey used a mixed methodology where semi-structured questionnaires were used to obtain both quantitative and qualitative primary data using the electronic devices (KoBo Collect software) to conduct the interviews, reaching a total of 770 marginalized youths. Findings from the survey show that vocational skills training, business, career guidance, multi-mixed behavioral and psychological interventions are major determinants of access to the job market for marginalized slum youths. To address youth unemployment, this article underlines the need for interventions that fall outside the regular limits of training and other labor market programs. Numerous young people looking for better jobs and livelihoods are indebted by variables that are not commonly considered in these programs. These incorporate, for instance, lack of access to credit which deters business enterprise. This article has featured solutions important for young people looking for their livelihood in self-employment and entrepreneurship.
\end{abstract}

Keywords: Job market, Youth Development, Unemployment, Youths

\section{Introduction}

As of 2018, there are 1.2 billion people aged 15-24 years, and the youth population comprises roughly one sixth of the world's population of 7.3 billion (Bank, 2018). By 2030 the target date for the sustainable development goals the youth population is projected to grow 7 percent to nearly 1.3 billion. Because of the sheer size of this demographic, the youth population can be a positive force for development, but only if provided with the knowledge and opportunities to thrive: Young people must acquire the education and skills needed to contribute in a productive economy, but they also need access to a job market that can absorb them into its labor force. Among the greatest challenges facing many countries today are inadequate human capital investment and high unemployment rates among youth (International Labour Organisation, 2018)

In addition, further findings from the Bank, 2018 report shows that official national unemployment rate in Uganda to have increased to 2.10 percent in 2017 from 2 percent in 2016; the same report states unemployment rate in Uganda averaged 2.38 percent from 1991 until 2017, reaching an all-time high of 3.50 percent in 2002 and a record low of 0.94 percent in 1991. These increases raise concerns about the rate of job creation, and especially about the social and political effects of high unemployment especially among the youths since Uganda is a young nation. The United Nations Sustainable Development Goals (SDGs) particularly goal 8 calls to promote sustained, inclusive and sustainable economic growth, full and productive employment and decent work for all (Deloitte Touche Tohmatsu Limited, 2016). By 2020 the same expects to substantially reduce the proportion of youth not in employment, education or training.

Copyright (C) 2019. The Author(s). Published by AIJR Publisher.

This is an open access article under Creative Commons Attribution-NonCommercial 4.0 International (CC BY-NC 4.0) license, which permits any non-commercial use, distribution, adaptation, and reproduction in any medium, as long as the original work is properly cited. 
Prior research by Blanchet-Cohen, Manolson, \& Shaw, 2014; Haroon \& Tarp, 2016 in other sub Saharan middle income countries like Nigeria and Kenya indicates that governments has channel their efforts towards employment programs to relieve poverty, spur economic growth, and bolster political support reference here or edit. In developing countries, especially fragile states, governments invest in employment and anti-poverty programs with additional motives in mind (Blanchet-Cohen et al., 2014) to strengthen the sense of citizenship and civic action, and to lessen the risk of social instability caused mainly by the growing populations especially the youths.

Majority youths in Uganda face problems that are mostly related to unemployment and this is greatly due to lack of relevant skills to enable them competing favorably in the fast-growing market. The study suggests that there is need for employment interventions that promote self-employment and new innovations based on vocational skilling and psychological empowerment. These findings seek to answer the following questions: What is the prevalence and availability of job market opportunities for Youths in Uganda? What factors influence youth access and reintegration in the job market of Uganda? What can be done to enhance access to job opportunities for the slum youths in Uganda? This paper seeks to answer some of these questions by examining the structure of unemployment in Uganda and changes in joblessness over the past years. With that brief overview, it should be noted that in order to promote inclusive economic development, youths including the marginalized youths should be engaged at all levels of the development process because they are mostly affected. Programs to ensure their economic freedom from extreme poverty thus leading to engaging in risky behaviors should be designed at policy level.

\section{Theory of Positive Youth Development}

This theory looks at the abilities, potential for development, and in expanding flourishing practices of youth as opposed to on their inadequacies (Damon, 2004; Matthews, 2002). By implementing these characteristics, a person's benefits are fabricated in this way shielding the person in question from health trading off practices, enhancing the opportunity for positive developmental outcomes, and building his or her versatility with an end goal to counter issues that may influence them (Benson P. L.; 2002; Manning \& Junankar, 1998; Seligman, 1999). Fundamentally, this theory tends to young people from a decent and positive point of view, as it sees them as assets as opposed to problems. As indicated by (Nordås \& Davenport, 2013) it focuses on that positive youth development rises when the potential versatility of human development is lined up with developmental assets.

It considers young people from a quality based point by perceiving that their unending potential is reliable with their qualities (Benson P. L.; 2002; Damon, 2004; Manning \& Junankar, 1998; Matthews, 2002; Seligman, 1999; Shepherd, Linda, \& Matthew, 2007). Of significance is that, despite the fact that the constructive youth development hypothesis praises association and interest of young people being developed procedures, it recognizes this exertion as being deficient and that more exertion ought to be made for youth to channel their energies to "positive headings" as this would make them to do things "dependably" while empowering institutional help (Checkoway, 2011). This hypothesis along these lines encourages young people (paying little mind to their problems) to utilize their capability minus all potential limitations and furthermore urges them to look for and get support from the human condition (e.g., family, peer gathering, the school, community). The job of the Youth specialists is make an empowering situation so as to deliver positive youth who can add to their families, networks, and society (Okojie, 2003).

\section{Determinants of Job Market Access for Marginalized Youths}

Youth unemployment and underemployment are serious concerns in sub-Saharan Africa, especially given the region's young population. The barriers young people face stem both from skills deficiencies and from weak fundamentals that constrain job creation more generally in the region (Ozerim, 2018). Employment interventions can mitigate some of these barriers. At the same time, young people in subSaharan Africa face difficult employment prospects. The majority work in low-productivity jobs, most often in agriculture or in self-employment or household enterprises (Manning \& Junankar, 1998). They 
Nakirijja et al., Adv. J Social Sci.; Vol. 6 Issue 1, pp: 26-37, 2020

have low earnings, little security, and limited possibilities for upward mobility. A substantial modern wage sector currently exists only in the region's few upper middle-income countries. Educated young people, particularly in these countries, may have better jobs when they do get them but open unemployment for this group is a serious concern. Some forecasts predict that wage employment will increase significantly in the coming years with expanding manufacturing and service industries (Martinez et al., 2014). However, it is overly optimistic to expect major changes in the region's job structure over the next decade, with most young people continuing to work in agriculture and household enterprises.

Table 1 gives summary indicators of youth unemployment from selected regions of the world. The data was extracted from the International Labour Organisation, 2018. The results show that sub Saharan region $(11.7 \%)$ of Africa only is affected by high rates of youth unemployment which pause a threat to the region's economic status, and this is partly due to the availability of youth bulge.

Table 1: Summary Indicators, youth employment (15-24 years), by region 2013

(Source; International Labor Office, ILO 2018)

\begin{tabular}{|l|l|l|l|l|}
\hline & $\begin{array}{l}\text { Unemployment } \\
\text { Rate }\end{array}$ & $\begin{array}{l}\text { Youth-to-adult } \\
\text { unemployment rate }\end{array}$ & $\begin{array}{l}\text { Labor force } \\
\text { participation rate }\end{array}$ & $\begin{array}{l}\text { Employment } \\
\text { Rate }\end{array}$ \\
\hline Sub-Saharan Africa & 11.7 & 2.0 & 53.6 & 47.3 \\
\hline Developed Economies & 17.9 & 2.3 & 47.5 & 38.0 \\
\hline $\begin{array}{l}\text { Central and Southeastern } \\
\text { Europe/CIS }\end{array}$ & 18.0 & 2.6 & 42.0 & 34.5 \\
\hline East Asia & 9.8 & 2.7 & 59.3 & 53.5 \\
\hline Southeast Asia and Pacific & 13.3 & 5.3 & 52.2 & 45.2 \\
\hline South Asia & 9.4 & 3.9 & 40.9 & 37.0 \\
\hline $\begin{array}{l}\text { Latin America and } \\
\text { Caribbean }\end{array}$ & 13.2 & 2.7 & 52.4 & 45.5 \\
\hline Middle East & 29.1 & 3.8 & 30.2 & 21.4 \\
\hline North Africa & 23.9 & 3.3 & 33.3 & 25.4 \\
\hline
\end{tabular}

Access to Job market by marginalized youth in Uganda is a tenacious problem which needs urgent attention. Notwithstanding Uganda's sustained economic growth over the past decade, the trends are not very encouraging for the increasing youth population. Youth (aged 12-30), constitute over 80 percent of Uganda's 40 Million populations (UBOS, 2016). Although being the majority of the population and the bedrock of the labor force, the optimal contribution of the youth to the development of the country is hampered by unemployment, low skill level, limited opportunities and vulnerability. $62 \%$ of Ugandan youth are jobless, more than 2 million youth are out of school, and majority of these have no regular work or income making them vulnerable to recruitment into illegal activities (Deloitte Touche Tohmatsu Limited, 2016)

Furthermore, some of the youths in Uganda are struggling out of the confines of unemployment through entrepreneurship and civic engagement in a less favoring society where their interests are less considered by those in position of power and responsibility. Despite (youths) limited to the informal sector, with less income for sustainability, this review argues that government should use the already existing institutions of youths to foster economic development. Moreover, the conventional wisdom among policymakers, the media, and many social scientists is that this bulge will weaken community and societal bonds and, many fear, heighten social unrest, including (in extreme cases) crime, riots, and even armed conflict and terrorism (Augsberger, Collins, Gecker, \& Dougher, 2018; Blanchet-Cohen et al., 2014; Martinez et al., 2014; Namakula, 2015; Nordås \& Davenport, 2013; Okojie, 2003). The case has been made that entrepreneurship is key to the sustainable development of sub-Saharan Africa (African Development Bank Group, 2013). The study of entrepreneurship has advanced significantly, showing greater research breadth, depth and rigor. 
To give a clear picture of the state of Unemployment especially in the urban areas of Uganda, a survey was conducted by a Non-Government Organization on some young people who underwent kills training within a period of 3 years. In response to the huge urban youth unemployment and limited access to job market, Uganda Youth Development Link (UYDEL) a Non-Profit organization implemented a three year project (1st August 2015- 31 st July 2018) titled, Access to the Job market for slum youths in Uganda. This project aimed to reach 1500 slum marginalized youths aged $14-25$ years with vocational skills training in Kampala, Mukono and Wakiso Districts, Uganda. The project focused largely on economic empowerment through the provision of vocational skills training (VT) to the slum marginalized youths with the aim of ensuring gainful employment opportunities and access to job market. These slum youths were trained to acquire these skills from the seven UYDEL youth drop in centers of project implementation namely; Kampala- Makindye, Kamwokya, Bwaise, Nakulabye, and Nateete, Wakiso-(Masooli- shelter) and Mukono-(Mukono). One of the interventions used by UYDEL to deliver to the various key populations and communities include; Socio-economic empowerment which is done through vocational skills training, street Business skills training, Internship placement, Startup Kit and Linkage to the private and public business sector for job placement and follow up during and after reintegration.

\section{Vocational Skills Education as a Major Component for Job Creation}

According to (Damon, 2004; Fox et al., 2014) vocational skills training refer to undergoing training in a special skill and knowledge to be pursued in a trade. UYDEL for the last 25 years has used the vocational skills training model as part of its empowerment for vulnerable and marginalized slum youth. The project Access to job market in Uganda used Vocational skills Training (Figure 1) as one of the major economic empowerment tools for the slum youth towards addressing the unemployment gap. UYDEL was tasked to identify slum youth from Kampala, Mukono and Wakiso districts, assess their home background, education level, drug and substance use, employment status.

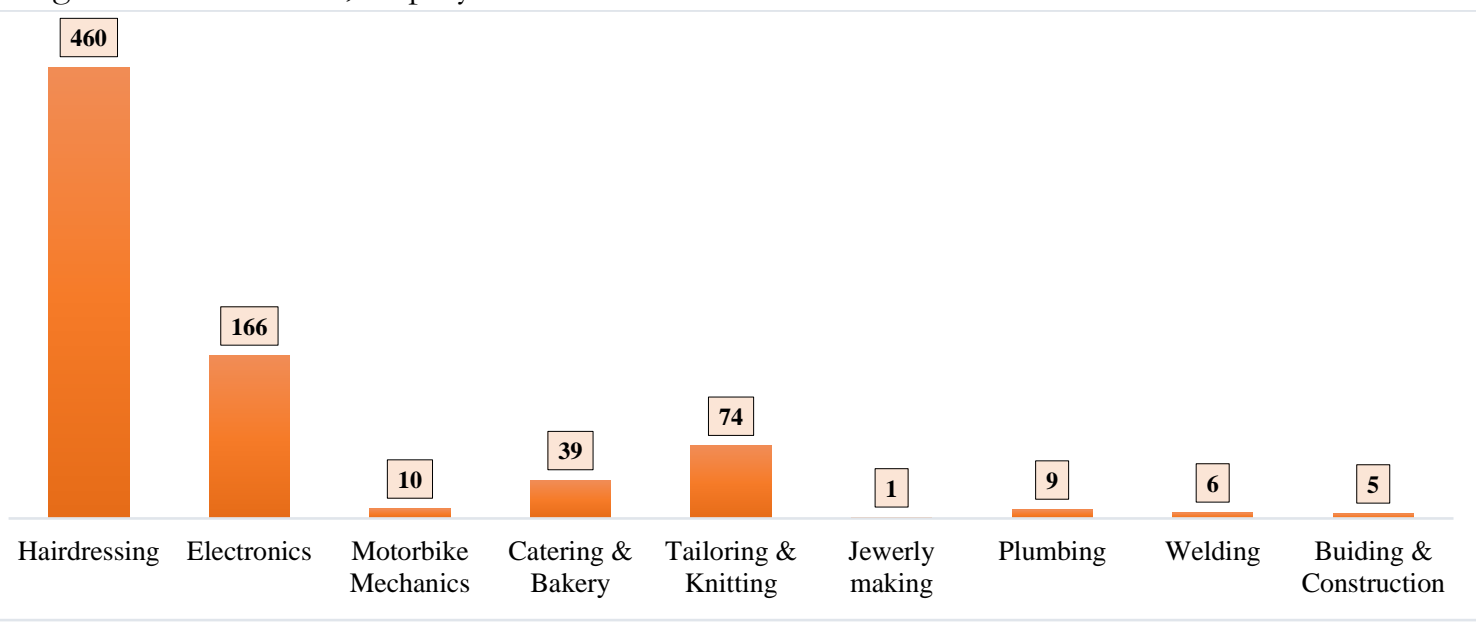

Figure 1: Skills attained by beneficiaries while at UYDEL

The finding show that young people or marginalized youths utilized the hairdressing skills, and this may be attributed to the possibility that since the projected registered more female, they took on the skill. In addition, electronics was also adopted by the marginalized youths and registered mostly male (as will be shown in later data)

\subsection{Business, Career Guidance, Skills Selection and Training}

The project was also interested in working together with the slum youth and upon a slum walk of business enterprises, the social workers help the youth to select a skill and are recruited for vocational training. The slum youths were free to select the vocational skills course of their choice after career guidance from the social workers and community resource persons. The skills are selected after conducting a market survey to map the viable employment opportunities that the slum youth can engage in after training. During the 
Nakirijja et al., Adv. J Social Sci.; Vol. 6 Issue 1, pp: 26-37, 2020

course of skills training, the slum youth are taken through a comprehensive business skills training, where they are taught about saving either as individuals or in groups (VSLA), drafting of business plans, managing businesses, selection of business location, book keeping, budgeting among others.

Table 2 shows data of the total number of marginalized youths that benefited from the program representing, a total of 1,988 slum youth where 599 males (29\%) and 1,389 females (72\%). The reasons for higher percentage of females than males include; the level of vulnerability in terms of violence, sexual harassment is more in females rather than males. These slum youth were trained in a variety of vocational skills from hairdressing, tailoring, knitting, catering, welding, electronics, and motorbike mechanics.

Table 2: Total Number of Youths reached by the project

\begin{tabular}{|c|c|c|}
\hline \multirow[t]{2}{*}{ Period of Training } & \multicolumn{2}{|c|}{ Gender } \\
\hline & Male & Female \\
\hline Aug 2015-Aug 2016 & 152 & 348 \\
\hline Sept 2016-Feb 2017 & 161 & 590 \\
\hline Feb 2017-July 2017 & 210 & 387 \\
\hline Aug 2017-Jan 2018 & 76 & 64 \\
\hline Total & 599 & 1389 \\
\hline
\end{tabular}

\subsection{Multi-mixed Behavioral and Psychological Intervention}

Marginalized (slum) youths who drop out from school at an early stage are most likely to engage in drugs and alcohol, in addition to juvenile delinquency (Benson P. L.; 2002). If access to job market is to succeed, additional skills in behavioral, life skills (relation/communication and social interactions), psychological (emotional, self-esteem, substance abuse control and drugs, depression, suicide, high risk sexual activities including prostitution homelessness, are vital because of the above tendencies, heterogeneity and different experiences. Such marginalized slum youths have gone through very traumatic experiences which cause depression and suicide, sexual exploitation, law enforcement challenges and successive, positive adjustment and recovery will require multi-faceted (buffet) interventions. Slum youths, because of their heterogeneity, mobility/attrition/drop out, distance of the safe space and survival crime tendencies responded differently to vocational skills training and therefore this required patience from social worker, artisan and even at the job placement.

\subsection{Vocational Training and Modular Assessment}

The youths after training in UYDEL vocational centers/safe space need to prove and show ability to apply limited range of knowledge and skills to perform specific and simple work tasks within routine and uniform structured contexts, including working with others under direct supervision. UYDEL registers the trained slum youths for Directorate of Industrial Training (DIT) assessment (modular assessment) for awarding certificates to successful candidates in relation to the evidence adduced of their respective competences in the form prescribed by the Minister of Education (Uganda) on the recommendation of the Council. By the time of the study, only 100 slum youths out of 770 reached in the survey had completed DIT.

This study noted that the DIT exams are very exorbitant (Ugx 150,000 for modular 1, Ugx 200,000 for level 1, Ugx 250,000 for level 2 and Ugx 100,000 for materials) but also some slum youths don't see it as important to sit for the exams. There is need for Government to do waiver the registration fees and on materials so as to enable many slum youths attain the certification level and upgrade to diploma for further levels of certification. In future organizations working with youths should increase budgets to support more slum youths to sit DIT exams.

In order to encourage more marginalized youths to take on these opportunities, young people are certified during Graduation as one of the methods done also to track slum youth. It involves giving our local certificates, follow up, document success stories and most significant change stories (MSC), initiation to the 
job market, graduation is an opportunity for slum youth to meet and discuss job opportunities, and where to access the job market opportunities.

Internship and Field Job placement is meant for the UYDEL trainees to go to job markets sometimes without pay in order to gain work experience and also prepare them for DIT exams from the skill acquired in saloon for hairdressing, Hotels for catering, welding workshops. Slum youth find internship placement through (staff, themselves, former beneficiaries, guardians, local leaders, NGOs, accomplished business owners, Parents and relative, youth trainers), Internship and recommendation letters, Exposure learning visits, for coaching and mentorship by accomplished businessmen. Internship helps slum youths to access jobs; they access work places as trainees who need to learn more at the job environment, others approach volunteers.

\section{Methods}

\subsection{Follow up of Slum Youth}

The survey used a mixed methodology where semi-structured questionnaires were used to obtain both quantitative and qualitative primary data using the electronic devices (tablet) to conduct the interviews. During the preparation of the survey, an orientation training of 15 research assistants were identified, interviewed and trained on the data collection tools, ethical issues such as consent, being responsible and nonjudgmental and how to approach enterprises where the slum youth were working so as not to cause unnecessary commotion were undertaken for purposes of every interviewee to be well versed with the data collection tools and the software used for programming the tool on the tablets. Figure 2 below shows the survey area of study. Marginalized slum youths who benefited the UYDEL programs from Kampala District were followed up to assess patterns in employability and access to the job market. Kampala District was selected because of the high concentration of youths and high rates of youth unemployment. It is divided into 5 divisions namely; Rubaga, Makindye, Kawempe, Nakawa and Central Regions.

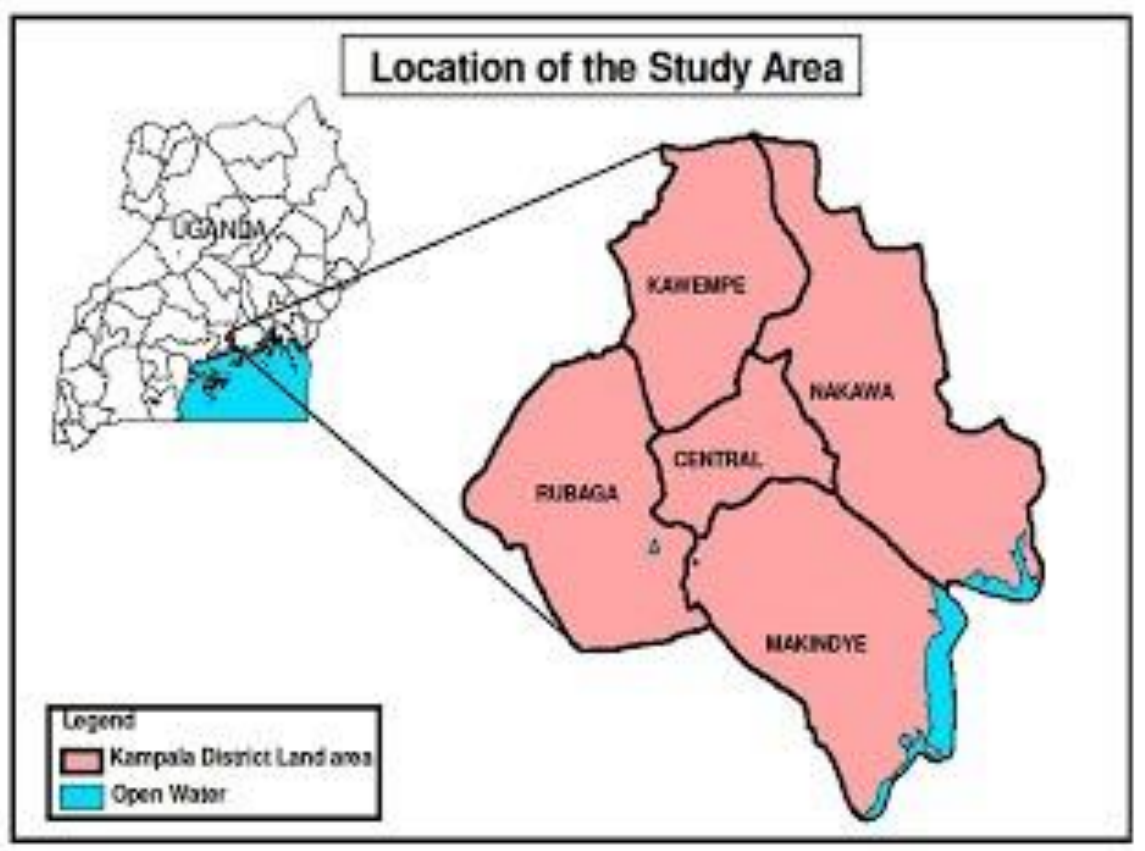

Figure 2: Study Area-Map of Kampala District

This survey followed up former beneficiaries of UYDEL who had graduated from the intervention programs (2015-2018) and centers of project implementation. This was a purposeful sampling which also involved use snow balling where youth tells you where their friends are. Since some had migrated to other places. Whoever showed up was captured interviewed in data collection). Data obtained from the follow up was collected using the KoBo Collect software and analyzed using the excel spread sheets. In order to 
Nakirijja et al., Adv. J Social Sci.; Vol. 6 Issue 1, pp: 26-37, 2020

capture some successful stories, a few slum youths were reached at their job market places by research assistants, but with permission from the employer as well as photos to be used in UYDEL reports the research assistants contacted the beneficiaries' through their cell phones seeking appointment to meet them at the center or at their work place.

Table 3 below shows the total number of youths reached during the follow up. Most of the young people were meant at the training centers. However, those that could have migrated from their former place of residence (living outside Kampala) were followed by phone calls.

Table 3: Total Number of Slum Youth reached during the survey

\begin{tabular}{|l|c|c|c|c|c|}
\hline \multicolumn{1}{|c|}{ Centers } & $\begin{array}{c}\text { Beneficiaries } \\
\text { contacted }\end{array}$ & $\begin{array}{c}\text { Met at } \\
\text { centers }\end{array}$ & $\begin{array}{c}\text { At work } \\
\text { place }\end{array}$ & $\begin{array}{c}\text { Phone } \\
\text { follow up }\end{array}$ & Not reached \\
\hline Masooli & 120 & 14 & 0 & 60 & 46 \\
\hline Bwaise & 150 & 68 & 0 & 0 & 82 \\
\hline Nateete & 240 & 129 & 0 & 25 & 72 \\
\hline Kamwokya & 208 & 46 & 0 & 79 & 0 \\
\hline Nakulabye & 99 & 79 & 0 & 20 & 0 \\
\hline Makindye & 319 & 96 & 0 & 68 & 135 \\
\hline Mukono & 140 & 25 & 32 & 63 & 20 \\
\hline
\end{tabular}

During the exercise, a total of 770 (220 males, 550 females) representing $51 \%$ of all former beneficiaries who participated in UYDEL's vocational skills training empowerment program were reached. The 49\% was not reached partly because some slum youth who had been trained, migrated from their places of initial residence and moved to distant places for work. The social workers lost contact with the beneficiaries because recently Government required registration of mobile contacts of which young people appear not to have registered. Some slum youths did not have telephone contacts and the guardian's phones were not readily available and changed residence making it difficult to contact the beneficiary. In addition, contacts provided at initial assessment by the slum youths had changed.

During follow up exercise, our research assistants were encouraged to undertake call backs, engage neighbors, use snow balling methodology where a former peer helps to identify another for purposes of the exercise, use of local leaders and use of home visit maps. The entire exercise was financially constrained, demanding and has a lot of processes. UYDEL learnt that in identification, training and follow up of slum youths one needs to have a comprehensive understanding of the youth social network, beyond the family and peers. Follow up exercise has shown that slum youths indeed change location to access job market. In future enough resources both financial and human are necessary to do a more comprehensive follow up. A onetime off follow up of the entire cohort is not sufficient to enable the results strong and generalizable. Subsequent follow up would make the case stronger and this may need to be funded in future. Figure 3 showing the total number of slum youths reached during the follow up by gender. The data shows that the research assistants were able to reach $71 \%$ of the overall number reached and only $29 \%$ of the former beneficiaries reached were males.

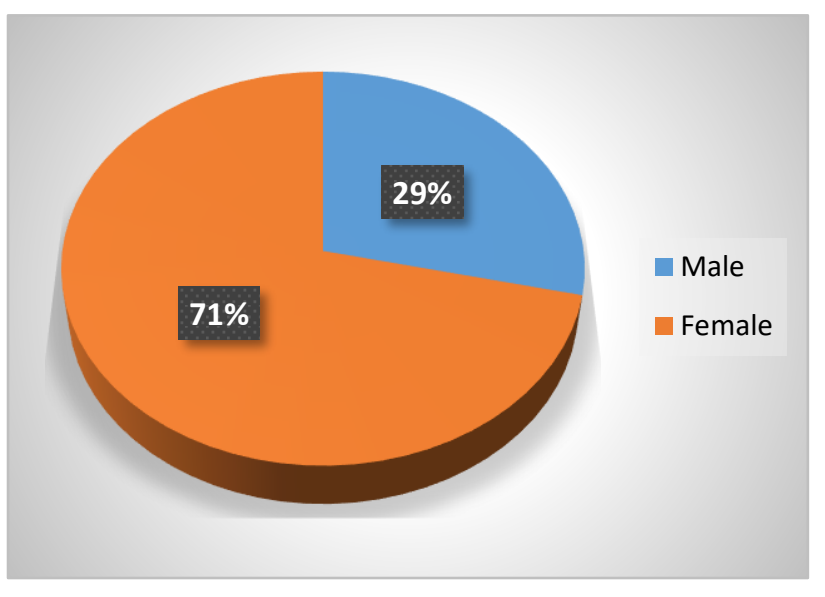

Figure 3: Number of Young people reached by Gender

Out of the 770 former beneficiaries reached, among those who were employed most were female with 39\% out of the overall of $57 \%$ of the beneficiaries who are employed. Most of the beneficiaries are the bread winners of their families evidenced from the results of who is the main household income earner and $24 \%$ 
Access to Job Market: Findings from A Venture Development Program for Marginalized Unemployed Youth in Kampala Uganda

are the beneficiaries. Almost all the beneficiaries' reached during the follow up survey their lives improved after UYDEL with $60 \%$.

\section{Results and Discussions}

\subsection{Access to Job Market}

To determine employment and access to job market, the survey was interested to find out how many slum youths who trained in UYDEL vocational training were absorbed in the job market. Overall, out of the 770 slum youths who were trained and reached by the research assistants' 75 percent were found working. These slum youths were either employed (57 percent) or self-employed (18 percent). The 25 percent who were not working, 14 percent were still job hunting. For those who were job hunting, some of the reason were due to many challenges as one youth quotes; “... sometimes we don't have tools and materials to start business, the rent and the capital is less to sustain a business...”. Table 4 below shows the overall frequencies of young people that were reached per drop in centers in Kampala and Mukono

Table 4: Total number of former beneficiaries reached by respective centers/safe space

\begin{tabular}{|l|r|r|r|r|r|r|}
\hline Characteristic & \multicolumn{2}{|c|}{ Gender } & Total & \multicolumn{2}{c|}{ Percent } & \\
\hline Overall & Male & Female & & Male & Female & Total \\
\hline Centre & 220 & 550 & 770 & 28.6 & 71.4 & 100.0 \\
\hline Bwaise & & & & & & \\
\hline Kamwokya & 10 & 58 & 68 & 1.3 & 7.5 & 8.8 \\
\hline Makindye & 40 & 94 & 134 & 5.2 & 12.2 & 17.4 \\
\hline Masooli & 27 & 109 & 136 & 3.5 & 14.2 & 17.7 \\
\hline Mukono & 50 & 39 & 89 & 6.5 & 5.1 & 11.6 \\
\hline Nakulabye & 36 & 86 & 122 & 4.7 & 11.2 & 15.8 \\
\hline Nateete & 29 & 63 & 92 & 3.8 & 8.2 & 11.9 \\
\hline
\end{tabular}

\subsubsection{Nature of Employment- Formal/Informal}

It was further revealed that amongst those working as shown in Table 5 below, 51 percent were in formal employment and the other 26 percent were in informal employment.

Table 5: Nature of Employment Engaged in by the Young People

\begin{tabular}{|l|r|r|r|r|r|r|}
\hline & \multicolumn{2}{|c|}{ Gender } & Total & \multicolumn{2}{c|}{ Percent } & \\
\hline & Male & Female & & Male & Female & Total \\
\hline Overall & 220 & 550 & 770 & 28.6 & 71.4 & 100.0 \\
\hline Currently employment status & & & & & & \\
\hline Employed & 135 & 302 & 437 & 17.5 & 39.2 & 56.8 \\
\hline Self-employed & 52 & 90 & 142 & 6.8 & 11.7 & 18.4 \\
\hline Still job hunting & 21 & 85 & 106 & 2.7 & 11.0 & 13.8 \\
\hline Peasants & 3 & 10 & 13 & 0.4 & 1.3 & 1.7 \\
\hline Nothing & 4 & 36 & 40 & 0.5 & 4.7 & 5.2 \\
\hline Other & 5 & 27 & 32 & 0.6 & 3.5 & 4.2 \\
\hline Nature of employment & & & & & & \\
\hline Both & 4 & 8 & 12 & 0.5 & 1.0 & 1.6 \\
\hline Formal & 123 & 268 & 391 & 16.0 & 34.8 & 50.8 \\
\hline Informal & 63 & 138 & 201 & 8.2 & 17.9 & 26.1 \\
\hline None & 30 & 136 & 166 & 3.9 & 17.7 & 21.6 \\
\hline
\end{tabular}




\subsection{Vocational Training Skills Utilization in the Job Market}

Learning and keeping a job, learning the skill is the quickest way to employment. Skills utilization by the slum youths is an indicator of the marketability and demand of a skill in the job market. The study was interested to know whether the skills obtained at UYDEL are the ones they are engaged in their employment). We wanted to look at those trained and using the skills acquired to access the job market verses employment. The data showed that 56 percent were utilizing the skills obtained from UYDEL and 42 percent said no. In terms of assistance to access a job, it was revealed that 31 percent did it by them. It was further revealed that most of these were slum youths who had trained in hairdressing (17 percent) and many and 16 percent by parents. It was further revealed that mode of pay is cash by cash basis.

\subsubsection{Savings and Financial Literacy}

This was very important during vocational skills training for the slum youths because saving helps to increase the income and capital base of the slum youths and this was our major goal during the period of skills training. The study inquired and established that 79 percent were saving some part of their income. Out of these 32 percent had become members of a saving group. The study shows that 41 ( 5 percent) of the slum youths had gone back to school. Further interviews revealed that 31 percent were saving money by self (box), this is one way where one buys a wooden box with a hole and inserts money inside as a way of saving and financial. 28 percent were in informal (unregistered) saving groups and 114 (18 percent) were saving in banks. A small number, 33 (5.4 percent) were saving through microfinance institutions. Table 6 below shows UYDEL beneficiaries reached during the survey were found to have been a major factor in improving capital base and the overall wellbeing of the slum youths. Saving skills culture should be a cardinal component of any vocational training and access to job market.

Table 6: Total Number of Slum Youth Saving some part of their income

\begin{tabular}{|c|c|c|c|c|c|c|}
\hline \multirow{2}{*}{ Characteristic } & \multicolumn{2}{|c|}{ Gender } & \multirow[t]{2}{*}{ Total } & \multicolumn{2}{|c|}{ Percent } & \multirow[b]{2}{*}{ Total } \\
\hline & Male & Female & & Male & Female & \\
\hline Overall & 220 & 550 & 770 & 28.6 & 71.4 & 100.0 \\
\hline \multicolumn{7}{|c|}{ Member of any Saving group } \\
\hline Yes & 81 & 167 & 248 & 10.5 & 21.7 & 32.2 \\
\hline No & 139 & 383 & 522 & 18.1 & 49.7 & 67.8 \\
\hline \multicolumn{7}{|c|}{ Saving some part of your income } \\
\hline Yes & 180 & 431 & 611 & 23.4 & 56.0 & 79.4 \\
\hline No & 40 & 119 & 159 & 5.2 & 15.5 & 20.6 \\
\hline \multicolumn{7}{|c|}{ Mode of saving income from business } \\
\hline None & 40 & 119 & 159 & 5.2 & 15.5 & 20.6 \\
\hline Bank & 49 & 63 & 112 & 6.4 & 8.2 & 14.5 \\
\hline Microfinance & 13 & 20 & 33 & 1.7 & 2.6 & 4.3 \\
\hline Informal saving groups & 56 & 116 & 172 & 7.3 & 15.1 & 22.3 \\
\hline Self (box) & 30 & 160 & 190 & 3.9 & 20.8 & 24.7 \\
\hline Other & 32 & 72 & 104 & 4.2 & 9.4 & 13.5 \\
\hline \multicolumn{7}{|l|}{ Amount saved monthly } \\
\hline N/A & 0 & 16 & 16 & 0.0 & 2.1 & 2.1 \\
\hline Less than shs5,000 & 44 & 139 & 183 & 5.7 & 18.1 & 23.8 \\
\hline $5,000-15,000$ & 22 & 65 & 87 & 2.9 & 8.4 & 11.3 \\
\hline $15,001-25,000$ & 30 & 53 & 83 & 3.9 & 6.9 & 10.8 \\
\hline $25,001-35,000$ & 17 & 55 & 72 & 2.2 & 7.1 & 9.4 \\
\hline $35,001-45,000$ & 14 & 42 & 56 & 1.8 & 5.5 & 7.3 \\
\hline $45,000-55,000$ & 16 & 58 & 74 & 2.1 & 7.5 & 9.6 \\
\hline More than shs55,000 & 77 & 122 & 199 & 10.0 & 15.8 & 25.8 \\
\hline
\end{tabular}




\subsection{Well-being}

Life after UYDEL and employment is a key indicator of successful recovery for unemployed slum youth coming out of vulnerability and deprivation. Out of the 396 slum youths interviewed; data has showed that the slum youth who trained were the main source of income for the household. The implication here is that the slum families (24 percent) are not only dependent on the slum youths but because the slum youth is working, he/she has now become the main bread winner in the household. The training provided by UYDEL in vocational skills comes in with two benefits; access to employment, and also the slum youth taking over the responsibilities of the family a hidden multiplier effect for the slum youths.

Table 7 shows that 93 percent of slum youth observed that life after UYDEL was either very good, good or fair of these 58 percent had spent more than one year out of UYDEL. The study was surprised that 41 (5 percent) of the slum youths had gone back to school. This statement coming from a slum youth is a big sign of an improved quality of life and successful adjustment after all these adversities they have gone through and experienced in the slum communities which UYDEL should be commended for.

Table 7: Well-being of marginalized youths after training period

\begin{tabular}{|c|c|c|c|c|c|c|}
\hline \multirow[t]{2}{*}{ Characteristic } & \multicolumn{2}{|c|}{ Gender } & \multirow[t]{2}{*}{ Total } & \multicolumn{2}{|c|}{ Percent } & \multirow[b]{2}{*}{ Total } \\
\hline & Male & Female & & Male & Female & \\
\hline Overall & 220 & 550 & 770 & 28.6 & 71.4 & 100.0 \\
\hline \multicolumn{7}{|c|}{ Period spent out of UYDEL } \\
\hline Less than 3 months & 4 & 23 & 27 & 0.5 & 3.0 & 3.5 \\
\hline 3-6 months & 48 & 183 & 231 & 6.2 & 23.8 & 30.0 \\
\hline 7-12 months & 17 & 52 & 69 & 2.2 & 6.8 & 9.0 \\
\hline More than 1 year & 151 & 292 & 443 & 19.6 & 37.9 & 57.5 \\
\hline \multicolumn{7}{|l|}{ Life after UYDEL } \\
\hline N/A & 0 & 1 & 1 & 0.0 & 0.1 & 0.1 \\
\hline Very good & 10 & 37 & 47 & 1.3 & 4.8 & 6.1 \\
\hline Good & 124 & 337 & 461 & 16.1 & 43.8 & 59.9 \\
\hline Fair & 76 & 145 & 221 & 9.9 & 18.8 & 28.7 \\
\hline Poor & 10 & 30 & 40 & 1.3 & 3.9 & 5.2 \\
\hline \multicolumn{7}{|l|}{ Currently in school } \\
\hline Yes & 13 & 28 & 41 & 1.7 & 3.6 & 5.3 \\
\hline No & 207 & 522 & 729 & 26.9 & 67.8 & 94.7 \\
\hline \multicolumn{7}{|c|}{ Relationship with family } \\
\hline Very good & 42 & 77 & 119 & 5.5 & 10.0 & 15.5 \\
\hline Good & 159 & 427 & 586 & 20.6 & 55.5 & 76.1 \\
\hline Fair & 16 & 30 & 46 & 2.1 & 3.9 & 6.0 \\
\hline Poor & 3 & 16 & 19 & 0.4 & 2.1 & 2.5 \\
\hline
\end{tabular}

\section{Conclusions}

Many of the former beneficiaries are facing problems with not receiving enough money at their workplace and they are in need of more capital. Change in location of the beneficiaries after the training process at the various UYDEL centers. Some beneficiaries provide contacts at the prior assessment level that are not valid which makes it hard to trace them after training. This can be addressed by providing at least 3 contacts by the beneficiaries during the assessment process. Lack of a proper tracking mechanism that can be used or be followed in the process of tracking the former beneficiaries that is in unison, some employers don't allow their workers in this case the former beneficiaries to be interviewed in the process of tracking and follow up which tends a big challenge for the whole process. Regular follow-ups and mentorships with the 
marginalized young people to recognize specific issues and also to identify adjustment that can be conducted at the training center, this can ensure the beneficiaries success in their skills after graduating. Provide the young people with more business mentorships and trainings, and support with linkages to job opportunities. In addition, there's needed to provide the former beneficiaries with more counseling and life skills sessions to ensure that the beneficiaries can be able to relate with their communities after reintegration. Furthermore, the program should provide the young people/slum youths with capacity building in business management, which can help them in proper monitoring and strengthening of their businesses. Encourage the former beneficiaries to save their money and explain to them the benefits with having saved up capital for the future. Enlarge the training package for the young people to include street smart behavioral change trainings.

\section{Declaration}

\subsection{Acknowledgements}

We thank the youths for assistance with in obtaining primary data and for their inputs that greatly improved the manuscript and for sharing their cases with us during the course of this research.

\subsection{Funding Source}

None

\subsection{Competing Interest}

The authors declared that no conflict of interest exist in publication of this work.

\subsection{Informed Consent}

Consent of respondents was sought from each respondent prior to engagement so that they don't feel coerced; the researchers had to request for consent from the respective respondents. An ethical form was signed and presented to every respondent and administrator at the time of interview. Thus, all information given by respondents was handled with confidentiality.

\section{How to Cite this Article:}

Nakirijja, D., Kasirye, R., \& Nabulya, A. (2019). Access to Job Market: Findings from A Venture Development Program for Marginalized Unemployed Youth in Kampala Uganda. Advanced Journal of Social Science,6(1), 26-37. doi: 10.21467/ajss.6.1.26-37

\section{References}

African Development Bank Group. (2013). African Development Bank Group 2013. Madagascar Economic Outlook. Retrieved from http://www.afdb.org/en/countries/central-africa/madagascar/madagascar-economic-outlook/

Augsberger, A., Collins, M. E., Gecker, W., \& Dougher, M. (2018). Youth Civic Engagement: Do Youth Councils Reduce or Reinforce Social Inequality? Journal of Adolescent Research, 33(2), 187-208. https://doi.org/10.1177/0743558416684957

Bank, W. (2018). The World Bank Annual Report 2018. https://doi.org/10.1596/978-1-4648-1296-5

Benson P. L.; (2002). Adolescent development in social and community context: A programme of research. New Directions for Youth Development, 95(Autumn), 123-148.

Blanchet-Cohen, N., Manolson, S., \& Shaw, K. (2014). Youth-Led Decision Making in Community Development Grants. Youth and Society, 46(6), 819-834. https://doi.org/10.1177/0044118X12455024

Checkoway, B. (2011). What is youth participation? Children and Youth Services Review, 33(2), 340-345. https://doi.org/10.1016/j.childyouth.2010.09.017

Damon, W. (2004). What Is Positive Youth Development? Annals of the American Academy of Political and Social Science, 591, 13-24. https://doi.org/10.1177/0002716203260092

Deloitte Touche Tohmatsu Limited. (2016). Uganda Economic Outlook 2016 The Story Behind the Numbers. 1-11. Retrieved from https://www2.deloitte.com/content/dam/Deloitte/ug/Documents/tax/Economic Outlook 2016 UG.pdf

Fox, L., Haines, C., ... Thomas, A. H. (2014). Africa's Got Work to Do: Employment Prospects in the New Century. IMF Working Papers, 13(201), i. https://doi.org/10.5089/9781484389195.001

Haroon, B., \& Tarp, F. (2016). Africa's Lions: Growth Traps and Opportunities for Six African Economies. Retrieved from https://www.brookings.edu/book/africas-lions-growth-traps-and-opportunities-for-six-african-economies/

International Labour Organisation. (2018). World employment social outlooks: Trends for 2018. Retrieved from http://ilo.org/wcmsp5/groups/public/---dgreports/---dcomm/---publ/documents/publication/wcms_615594.pdf 
Manning, C., \& Junankar, P. N. (1998). Choosy youth or unwanted youth? A survey of unemployment. Bulletin of Indonesian Economic Studies, 34(1), 55-93. https://doi.org/10.1080/00074919812331337280

Martinez, S., Humphreys, M., Katz, L., Kaur, S., Limlim, R., Pimhidzai, O., ... Morse, B. (2014). GENERATING SKILLED SELFEMPLOYMENT IN DEVELOPING COUNTRIES : EXPERIMENTAL EVIDENCE FROM UGANDA * Christopher Blattman Nathan Fiala I . Introduction A third of the world's population is aged 16 to 35 and lives in a less developed country . 1 A large numb. The Quarterly Journal of Economics, 697-752. https://doi.org/10.1093/qje/qjt057.Advance

Matthews, H. (2002). Citizenship, Youth Councils and Young People's Participation. Journal of Youth Studies, 4(3), $299-318$. https://doi.org/10.1080/13676260120075464

Namakula, H. (2015). Ensuring Safety in Search of Opportunity: Policy Options for Confronting Unsafe Labour Migrations among Ugandan Youth Based on an assessment of migrations to the Gulf Cooperation Council countries. 26-35.

Nordås, R., \& Davenport, C. (2013). Fight the Youth: Youth Bulges and State Repression. American Journal of Political Science, 57(4), 926940. https://doi.org/10.1111/ajps.12025

Okojie, C. E. E. (2003). Employment Creation for Youth in Africa: The Gender Dimension. Expert Group Meeting OnJobs for Youth: National Strategies for Employment, (Mm), 1-18.

Ozerim, M. G. (2018). Can the Youth Bulge Pose a Challenge for Turkey? A Comparative Analysis Based on MENA Region-Driven Factors. Young, 37-39. https://doi.org/10.1177/1103308818797792

Seligman, M. E. P. (1999). Positive social science. Journal of Positive Behavior Interventions, 1(3), 181-182. https://doi.org/10.1177/109830079900100306

Shepherd, Z., Linda, C., \& Matthew, C. (2007). Toward an understanding of youth in community governance : Policy priorities and research directions (*). Analoise Psicologica, 1(XXV), 77-95. https://doi.org/10.14417/ap.431

UBOS. (2016). National Service Delivery Survey 2015 Report. Retrieved from http://www.ubos.org/onlinefiles/uploads/ubos/pdf documents/2015 NSDS report.pdf

Publish your research article in AIJR journals-

$\checkmark \quad$ Online Submission and Tracking

$\checkmark$ Peer-Reviewed

$\checkmark \quad$ Rapid decision

$\checkmark \quad$ Immediate Publication after acceptance

$\checkmark \quad$ Articles freely available online

$\checkmark \quad$ Retain full copyright of your article.

Submit your article at journals.aijr.in
Publish your books with AIJR publisher-

$\checkmark \quad$ Publish with ISBN and DOI.

$\checkmark$ Publish Thesis/Dissertation as Monograph.

$\checkmark$ Publish Book Monograph.

$\checkmark$ Publish Edited Volume/ Book.

$\checkmark \quad$ Publish Conference Proceedings Retain full copyright of your books.

Submit your manuscript at books.aijr.org 